\title{
Allium White Rot Suppression with Composts and Trichoderma viride in Relation to Sclerotia Viability
}

\author{
E. Coventry, R. Noble, A. Mead, F. R. Marin, J. A. Perez, and J. M. Whipps
}

First, second, third, and sixth authors: Warwick HRI, University of Warwick, Wellesbourne, Warwick, CV35 9EF, U.K.; and fourth and fifth authors: Agrotechnology Department, Universidad Miguel Hernandez, Orihuela, Alicante, Spain. Accepted for publication 18 April 2006.

\section{ABSTRACT}

Coventry, E., Noble, R., Mead, A., Marin, F. R., Perez, J. A., and Whipps, J. M. 2006. Allium white rot suppression with composts and Trichoderma viride in relation to sclerotia viability. Phytopathology 96:1009-1020.

Allium white rot (AWR) is a serious disease of Allium spp. caused by the sclerotium-forming fungus Sclerotium cepivorum. This work has examined the effects of onion waste compost (OWC) and spent mushroom compost (SMC), with and without Trichoderma viride S17A, on sclerotia viability and AWR in glasshouse and field experiments. Incorporation of OWC into soil reduced the viability of sclerotia and the incidence of AWR on onion plants in glasshouse pot bioassays, whereas SMC or T. viride S17A only reduced incidence of AWR. In two field trials, OWC reduced sclerotia viability and was as effective in reducing AWR as a fungicide (Folicur, a.i. tebuconazole). Field application of SMC had no effect on sclerotia viability and did not control AWR. However, the addition of T. viride S17A to SMC facilitated proliferation of T. viride S17A in the soil and increased the healthy onion bulb yield. The results indicate two mechanisms for the suppression of AWR: (i) reduction in the soil population of viable sclerotia, which may be due to volatile sulfur compounds detected in OWC but absent in SMC, and (ii) prevention of infection of onion plants from sclerotia following amendment of soil with OWC, SMC, or T. viride S17A.

Additional keywords: biocontrol agent.
Allium white rot (AWR) is a serious disease of onion (Allium cepa L.) and other Allium spp. that has a significant economic impact on crop yields (10). The disease is caused by the soilborne pathogen Sclerotium cepivorum Berk. and attacks the root system of host plants, resulting in either death before harvest or postharvest decay (17). The pathogen survives in the soil as sclerotia and may remain dormant in this state in the absence of a host for more than 20 years (11). Sclerotia are stimulated to germinate by volatile thiols and sulfides released by soil microorganisms from alk(en)yl cysteine sulfoxides secreted from the roots of Allium spp. (12).

In the United Kingdom, the only approved fungicide which is effective in controlling AWR is Folicur, a.i. tebuconazole (9). In the United States and Canada, only dicarboximide fungicides (iprodione and vinclozolin) are registered for controlling AWR (36), but they frequently lose effectiveness due to enhanced microbial degradation in the soil (37). A number of alternatives to fungicides have been investigated to attempt to control the disease. These methods include solarization (25), the use of biological control agents (BCAs) (9), and sclerotia germination stimulants such as di-allyl disulphide (DADS) (12), but there have been problems with inconsistent control. Composts have been used to suppress various soilborne pathogens $(24,28)$. Loss of the diseasesuppressive effect of composts following sterilization $(20,28)$ indicates that the suppressive effect was predominantly biological rather than physical or chemical in nature. However, Smolinska (34) and Coventry et al. (15) found that incorporation of Brassica spp. wastes, which release toxic sulfur-containing compounds during decomposition, results in degradation of $S$. cepivorum sclerotia in soil. Coventry et al. $(14,15)$ found that application of onion waste compost (OWC) resulted in very effective degra-

Corresponding author: R. Noble; E-mail address: ralph.noble@warwick.ac.uk

DOI: 10.1094/PHYTO-96-1009

(C) 2006 The American Phytopathological Society dation of sclerotia of $S$. cepivorum in soil, possibly due to volatile sulfur-containing compounds stimulating sclerotia to germinate prematurely. However, the ability of OWC to degrade sclerotia in different soils did not entirely correspond to its AWR control efficacy in glasshouse pot tests (15).

To improve the consistency of control of soilborne pathogens using composts, BCAs such as Trichoderma spp. have been used as compost amendments (28). Clarkson et al. $(8,9)$ identified two isolates of Trichoderma viride (S17A and L4) with the capacity to degrade sclerotia and control AWR in the glasshouse and field, although performance was variable. Trichoderma spp. are known to be poor competitors in natural soil but can initiate effective competitive growth upon addition of a suitable nutrient source (30). Adams (2) indicated that, for Trichoderma to achieve control of soilborne pathogens, at least $10^{5}$ propagules/g of soil are required. Trichoderma species are known to be good colonizers of composts, such as mushroom compost (33); therefore, these may provide a nutritional substrate for Trichoderma spp. with AWR control activity, and enhance the AWR control efficacy compared with composts or BCAs alone.

The objectives of this work were to determine (i) the ability of different composts to control AWR under glasshouse and field conditions, (ii) the effect of amending composts with $T$. viride (S17A) on AWR control, (iii) the chemical and microbial properties of composts and soil + compost mixtures that relate to their suppressive activity, and (iv) the relative effects of composts and T. viride (S17A) on S. cepivorum sclerotia and AWR to determine their suppressive mechanisms.

\section{MATERIALS AND METHODS}

Organisms. The isolate of $S$. cepivorum used in this study was obtained from infected onions growing in Kirton, Lincolnshire, UK. Sclerotia required for the glasshouse pot bioassays and field trials were generated on a sand-maize medium and conditioned in soil before use (14). 
T. viride S17A was grown on potato dextrose agar (PDA). An initial PDA-grown culture was used to inoculate a sterilized mixture of rye grain and oat flakes $(10: 1, \mathrm{wt} / \mathrm{wt})$ in a solid-state fermenter system (Prophyta GmbH, Malchow/Poel, Germany). The colonized substrate was mixed $(15 \% \mathrm{vol} / \mathrm{vol})$ with horticultural grade perlite (Silvaperl Products Ltd., Harrogate, UK) to produce a $T$. viride $\mathrm{S} 17 \mathrm{~A}$ inoculum (initial count $=7.67 \times 10^{5} \mathrm{CFU} / \mathrm{g}$ ) for amending composts.

Composts. $O W C$. Wet (peelings and chopped bulbs) and dry (shale) onion wastes were mixed in a 10:1 ratio to produce a feedstock mixture with an $80 \%$ (wt/wt) moisture content (14). Urea was added at $4 \mathrm{~g} / \mathrm{kg}$ (14). For the glasshouse pot bioassays, the OWC was prepared using a small-scale flask composting system (14). Aeration maintained a minimum of $13 \%$ (vol/vol) $\mathrm{O}_{2}$ in the waste. For the field trials, the waste mixture was composted for 7 days at 50 to $53^{\circ} \mathrm{C}$ in 6-tonne (t)-capacity aerated bulk tunnels (29). A controlled flow of air of 200 to $900 \mathrm{~m}^{3} / \mathrm{h}$ into the plenum of the tunnels and through the waste maintained a minimum $\mathrm{O}_{2}$ concentration of $14 \%(\mathrm{vol} / \mathrm{vol})$ and ensured that the entire mass reached the temperature required (29). The OWC was prepared immediately before field application (fresh compost) or 2 to 5 months before field application and stored with an average compost temperature of $40 \pm 9.0^{\circ} \mathrm{C}$ (stored compost).

Spent mushroom compost. The spent mushroom compost (SMC) (Warwick HRI, UK) was approximately 1 month old and consisted of a mixture of casing material (peat and lime) and composted substrate (wheat straw, poultry manure, and gypsum) after cultivation of button mushrooms (Agaricus bisporus) (19).

Yard trimmings compost. Yard trimmings waste, a mixture of parks and gardens wastes, including prunings and leaves, was composted in windrows for a period of 5 months to produce the yard trimmings compost (YTC) (J. Moody Ltd., Wolverhampton, UK).

Pot bioassays. Two glasshouse pot bioassays, as described by Coventry et al. (15), were set up to determine the effect of OWC, SMC, YTC, and T. viride S17A on sclerotia viability and AWR. Each bioassay consisted of two complementary sets of pots (A and B) which were used for examining the effects of compost treatments on sclerotia viability (A) and AWR (B) with the same soil.

In bioassay 1 , the onion waste was incubated with aeration at eight temperatures ranging from 42 to $70^{\circ} \mathrm{C}$ at $4{ }^{\circ} \mathrm{C}$ intervals for 7 days. Onion waste also was incubated at $50^{\circ} \mathrm{C}$ for 7 days anaerobically. The composts (OWC, SMC, and YTC) were incorporated at two rates, 25 and $50 \%$ (vol/vol), into sieved (5-mm) sandy silt loam (Kirton, Lincolnshire, UK) soil containing $20 \%$ ( $\mathrm{vol} / \mathrm{vol})$ vermiculite to prevent clumping of the soil.

In bioassay 2 , both onion waste composted aerobically at $50^{\circ} \mathrm{C}$ and SMC were used. The composts were incorporated at two rates, 25 and $50 \%$ (vol/vol), into sandy silt loam soil with vermiculite. The $T$. viride $\mathrm{S} 17 \mathrm{~A}$ inoculum was incorporated into the soil and soil + compost (OWC and SMC) mixtures at a rate of $1.4 \mathrm{~g} / \mathrm{liter}$.

To determine the effect of the existing microbiota in the composts and soil, irradiated treatments were included in both bioassays. For this, the soil, vermiculite, and composts (onion waste incubated aerobically at $50^{\circ} \mathrm{C}$ for 7 days in bioassays 1 and 2, and SMC in bioassay 2) were irradiated with gamma rays (37 kGy) (Technical Service Consultants Ltd., Heywood, Lancashire, UK) after mixing, prior to set up. Nonamended soil and vermiculite mixtures, with and without irradiation, were used as control treatments in both bioassays.

Square pots (70 by 70 by $80 \mathrm{~mm}$, Optipots; LBG Ltd., Evesham, UK) were used for sets A and B. The matric potentials of the soil and soil + compost mixtures in the pots were monitored with miniature electronic pressure transducer tensiometers (type SWT5; Delta-T Devices, Ltd., Cambridge, UK) connected to a logger (type DLZe; Delta-T Devices, Ltd.). The pots were wa- tered from the bottom at regular intervals to maintain a matric potential of -2 to $-7 \mathrm{kPa}$.

The glasshouse heating set points were $14^{\circ} \mathrm{C}$ during the day and $12^{\circ} \mathrm{C}$ at night, and the ventilation set points were $18^{\circ} \mathrm{C}$ during the day and $16^{\circ} \mathrm{C}$ at night. The air temperature in the glasshouse was monitored throughout the course of the bioassays.

Effect of composts and T. viride S17A treatments on viability of sclerotia. Five polyester mesh bags (20 by $20 \mathrm{~mm}, 150-\mu \mathrm{m}$ mesh diameter) containing $2 \mathrm{~g}$ of 50:50 (vol/vol) sand/soil and $100 \mathrm{scle}-$ rotia were buried in the soil and soil + compost mixtures in the set A pots in each bioassay. Mesh bags were retrieved at 1, 3, 6, 9, and 12 months after adding to the pots. Sclerotia were recovered from the bags, counted, and assessed for viability, indicated by hardness and the ability to germinate on PDA (maximum of 30) (15). Soft sclerotia were considered degraded and regarded as nonviable (34).

Bioassay 1A was arranged as a randomized complete block design with four replicates and 27 pots per replicate. Each replicate contained 2 control (without irradiation) pots and 1 irradiated control pot, plus 24 pots comprising all combinations of the two incorporation rates for 12 compost treatments (OWC produced at eight temperatures from 42 to $70^{\circ} \mathrm{C}$; anaerobically incubated OWC; irradiated OWC, SMC, and YTC). Initial analyses indicated negligible differences between the effects of the OWC produced at temperatures between 42 and $66^{\circ} \mathrm{C}$ (including the anaerobically incubated treatment); therefore, subsequent analyses combined these treatments.

Bioassay $2 \mathrm{~A}$ also was arranged as a randomized complete block design with four replicates and 15 pots per replicate. The treatments comprised a control (nonamended soil) plus soils with OWC or SMC incorporated at 25 or $50 \%$ (vol/vol). These five treatments also were examined with the addition of $T$. viride $\mathrm{S} 17 \mathrm{~A}$ inoculum or after irradiation.

For bioassays $1 \mathrm{~A}$ and $2 \mathrm{~A}$, a measure of the effect of each treatment on the viability of sclerotia was obtained by multiplying together the observed proportion of recovered sclerotia, the observed proportion of undegraded (hard) sclerotia, and the observed proportion of germinated sclerotia. The proportion values obtained then were converted to percentages and subjected to analysis of variance following an arcsine transformation to cope with the anticipated heterogeneity of variance.

Effect of composts and T. viride S17A treatments on AWR. The soil + compost mixtures and soil alone were infested with conditioned sclerotia (3 sclerotia/g of mixture in bioassay $1 \mathrm{~B}$ and 10 sclerotia/g of mixture in bioassay 2B) and left in a glasshouse for 2 months in polyethylene bags. Pots were filled with the soil + compost mixtures or soil alone and a 4-week-old onion seedling (cv. Centurion) was transplanted into each pot. Pots with the soil + compost mixtures and soil alone with no sclerotia added were included to determine the effect of the composts on plant growth.

All plants were watered with a nutrient solution ( $2 \mathrm{~N}: 1 \mathrm{P}: 4 \mathrm{~K})$ weekly. The pots were assessed weekly for up to 20 weeks for the presence of AWR, which was scored as dead plants with visible mycelium or sclerotia. Non-AWR plant deaths also were recorded. In bioassay $2 \mathrm{~B}$, the final weight of the healthy plants grown in the different treatments was recorded.

In bioassay $1 \mathrm{~B}$, the treatments (with two plots of the nonirradiated control per replicate) were arranged following an $\alpha$ design for nine blocks of three plots per replicate. Each plot consisted of two subplots, one inoculated with sclerotia and the other uninoculated, with each subplot containing six pots, each containing a single onion seedling. Analyses considered only the data from the inoculated subplots, and the experiment was analyzed assuming a randomized complete block design with four replicates and 27 plots per replicate. Initial analyses considered the full treatment set but, as for the sclerotial viability bioassay 1A, there were negligible differences between the effects of the OWC produced at temperatures between 42 and $66^{\circ} \mathrm{C}$ (including the anaerobically 
incubated treatment); therefore, these treatments were combined in further analyses.

Bioassay 2B was arranged as a split-plot design with three replicates, each replicate containing six main plots, each main plot containing five plots, and each plot containing six pots, each containing a single onion seedling. The subplot treatments comprised an unamended control plus soils with OWC or SMC incorporated at 25 or $50 \%$ (vol/vol). The main-plot treatments comprised the combinations of the three supplementary treatments (unmodified, with addition of $T$. viride S17A inoculum, and irradiated) both with and without inoculation with sclerotia.

The analyses for bioassays $1 \mathrm{~B}$ and $2 \mathrm{~B}$ assessed the effects of the treatments on the number of AWR plant deaths, the number of non-AWR plant deaths, and the total number of plant deaths, each at the end of the assessment period (20 weeks) as proportions of the total number of plants per plot (usually six) within a generalized linear model (GLM) analysis assuming a binomial error distribution and logit link function, and allowing the dispersion parameter to be estimated. Interest was only in treatments that reduced the proportion of plants with AWR; therefore, a one-sided $t$ test was used to assess the significance of treatment effects. For bioassay $2 \mathrm{~B}$, the analysis model included terms for all the blocking structures, but compared all treatment terms with the subplot error term. For the uninoculated plots, mean plant weight at the end of the assessment period was assessed using analysis of variance, assuming the correct split-plot design.

Analysis of composts. The dry matter and ash contents, and $\mathrm{pH}$ of the composted wastes were determined (3). Samples of OWC, SMC, and YTC used to set up the pot bioassays were analyzed using gas chromatography (GC) with a Hewlett Packard model HP 6890 plus (Hewlett-Packard Company, Palo Alto, CA) for the presence of volatile sulfur-containing compounds and carboxylic acids. For sulfur compounds, the samples were extracted with water followed by diethyl ether (5). The extracts were analyzed by GC (inlet temperature $200^{\circ} \mathrm{C}$; detector temperature $300^{\circ} \mathrm{C}$; oven temperature $65^{\circ} \mathrm{C}$ for $2 \mathrm{~min}$, then $10^{\circ} \mathrm{C}$ increase per min up to $260^{\circ} \mathrm{C}$, and held at $260^{\circ} \mathrm{C}$ for $10 \mathrm{~min}$ ) using a Carbowax HP-5MS column (carrier gas helium with flow rate of $1 \mathrm{ml} / \mathrm{min}$ ) and flame ionization detector (FID). For the carboxylic acids, the samples were extracted with acidified water $(\mathrm{pH} 2)$ (16). The carboxylic acid content of the extracts was analyzed by $\mathrm{GC}$ (inlet temperature $150^{\circ} \mathrm{C}$; detector temperature $260^{\circ} \mathrm{C}$; oven temperature $50^{\circ} \mathrm{C}$ for $2 \mathrm{~min}$, then $10^{\circ} \mathrm{C}$ increase per min up to $220^{\circ} \mathrm{C}$, and held at $220^{\circ} \mathrm{C}$ for $2 \mathrm{~min}$ ) using an Innowax $19091 \mathrm{~N}-133$ column (carrier gas helium with flow rate of 0.7 $\mathrm{ml} / \mathrm{min}$ ) and FID.

Fungal propagules present in the OWC produced at 50 and $70^{\circ} \mathrm{C}$ were isolated using the method of Grogan et al. (21) and identified visually.

Field trials. Two field trials were conducted on adjacent experimental sites in Kirton, Lincolnshire, UK during 2000-01 (field trial 1) (Table 1) and 2002-04 (field trial 2) (Table 2). The soil type was a sandy silt loam as used for the pot bioassays. Sclerotia, mixed with sand, were spread uniformly over the experimental sites in July 2000 (field trial 1) and September 2002 (field trial 2) using a garden lawn spreader (The Scotts Company, $\mathrm{OH}$ ) to give $0.4 \mathrm{~g} / \mathrm{m}^{2}$ (approximately $14,000 \mathrm{sclerotia} / \mathrm{m}^{2}$ ). The experimental sites were arranged in plots $1.8 \mathrm{~m}$ wide consisting of four 6-m-long rows, with a guard plot between each experimental plot. Compost treatments were applied as a 75-mm layer, rotovated to a depth of $150 \mathrm{~mm}$ to produce a rate in soil of $50 \%$ ( $\mathrm{vol} / \mathrm{vol})$; control plots had no compost applied. Polyester mesh bags of sclerotia, as described for the pot bioassays, were buried in the plots at a depth of $100 \mathrm{~mm}$ in August 2000 (field trial 1) and September 2002 (field trial 2). The bags later were retrieved and sclerotia were assessed for degradation and germination. Onion sets $(n=660)$ were planted in each plot using a mechanical set planter at a depth of $25 \mathrm{~mm}$. Emergence of sets was recorded in four (field trial 1) or two (field trial 2) randomly selected 1-m lengths within each plot. The number of AWR-affected plants (dead plants with mycelium or sclerotia) was assessed in the same 1 -m lengths. Onion bulbs from each plot were stored for 1 month after harvest, then graded into three size categories $(<40 \mathrm{~mm}, 40$ to $60 \mathrm{~mm}$, and $>60 \mathrm{~mm}$ in diameter) and weighed, and the presence or absence of AWR was recorded.

Onion emergence data were expressed as a percentage of the number planted and were subjected to an arcsine transformation prior to analysis. The AWR levels were expressed as the number of affected plants as a cumulative percentage of the total number of emerged plants; these percentages also were subjected to an arcsine transformation prior to analysis. Data on the viability of sclerotia retrieved from bags were analyzed as described in the pot bioassays. Yield data were summarized in terms of the number and weight of onions in the size grades defined above, both with and without AWR. The data for number of onion bulbs were square root transformed prior to analysis. All transformations of data prior to analysis were to satisfy the assumption of homogeneity of variance.

The soil temperature at a depth of $100 \mathrm{~mm}$ was recorded daily for the duration of the field trials.

Field trial 1 (2000-01). Stored or fresh OWC was applied to plots in either August 2000 or April 2001 at 79 t of compost dry matter/ha. Bags of sclerotia were retrieved in June 2001, 10 months after the compost application in August 2000 and 2 months after the compost application in April 2001. Onion sets were planted in April 2001 (cv. Centurion, an early-maturing Sturon type) and May 2001 (cv. Hystar, a late-maturing Rijnsburger type). Onion sets dipped for $20 \mathrm{~min}$ in a fungicide solution (Folicur at 0.5 g/liter, a.i. tebuconazole at 250 g/liter; Bayer plc., Bury St. Edmunds, Suffolk, UK) also were planted in plots untreated with compost. The experimental area was fertilized with ammonium nitrate prior to planting $(261 \mathrm{~kg} / \mathrm{ha})$ and after seedling emergence $(101 \mathrm{~kg} / \mathrm{ha})$. Emergence of sets was recorded over a 4-week period following planting. The number of AWR-affected plants was assessed in July, August, and September 2001. Bulbs were harvested in August and September 2001 for cvs. Centurion and Hystar, respectively.

The trial originally was designed as a randomized complete block design for 10 treatments in six replicate blocks. The limited availability of some of the OWC caused the complete omission of one of the original treatments and the partial omission of another. This resulted in 12 replicate plots of one of the untreated control treatments and 9 of the other. The resulting unbalanced design could not be analyzed assuming the original blocking structure; hence, the collected data were analyzed using REML (35) to allow for variation both across and along the original replicate blocks. On some occasions, analyses were based on only the subset of plots assessed. The analysis approach described was able to allow for these incomplete data sets.

Field trial 2 (2002-04). Fresh OWC and SMC were applied and incorporated into plots of treatments E, G, I, and K (Table 2)

TABLE 1. Treatments and planting dates for onion sets in field trial 1 (2000-01)

\begin{tabular}{lllc}
\hline $\begin{array}{l}\text { Compost application or } \\
\text { other treatment }^{\mathrm{a}}\end{array}$ & $\begin{array}{c}\text { Planting } \\
\text { date, 2001 }\end{array}$ & $\begin{array}{c}\text { Onion } \\
\text { cultivar }\end{array}$ & $\begin{array}{c}\text { No. of } \\
\text { plots }\end{array}$ \\
\hline Control (untreated soil or sets) & April & Centurion & 12 \\
Control (untreated soil or sets) & May & Hystar & $9^{\mathrm{b}}$ \\
Folicur-dipped sets & April & Centurion & 6 \\
Folicur-dipped sets & May & Hystar & 6 \\
Fresh OWC, August 2000 & April & Centurion & 6 \\
Fresh OWC, August 2000 & May & Hystar & 6 \\
Stored OWC, August 2000 & May & Hystar & 3 \\
Fresh OWC, April 2001 & May & Hystar & 6 \\
Stored OWC, April 2001 & May & Hystar & 6 \\
\hline
\end{tabular}

a $\mathrm{OWC}=$ onion waste compost.

b Only six plots were assessed for sclerotia retrieval data. 
in September 2002 at rates of 73 and $76 \mathrm{t}$ of compost dry matter/ha for OWC and SMC, respectively. Wheat (cv. Tanker) was sown over the trial site in December 2002 and was mown in August 2003. Second applications of OWC and SMC were applied to relevant plots in September 2003 at the same rates as in the first applications. T. viride S17A inoculum was applied at a rate of $100 \mathrm{~g} / \mathrm{m}^{2}$ to the surface of relevant plots to which compost had been applied on the second occasion (i.e., treatments $\mathrm{H}$ and $\mathrm{L}$ ). T. viride S17A inoculum also was applied to untreated soil infested with $S$. cepivorum in two of five adjacent plots to the main field trial design (treatment $\mathrm{M}$ ). T. viride $\mathrm{S} 17 \mathrm{~A}$ inoculum was raked over the surface of plots and allowed to colonize the composts for 2 weeks prior to rotovating the composts into the plots. At the time of applying the T. viride S17A inoculum, additional bags of sclerotia were buried in plots which had received no compost (treatments $\mathrm{A}, \mathrm{B}, \mathrm{C}$, and $\mathrm{D}$ ) or had received compost only during the second year of the trial (treatments $\mathrm{F}, \mathrm{H}$, J, and L). Bags of sclerotia were retrieved in August 2003 and before onion set planting in April 2004.

The experimental area was fertilized with ammonium nitrate (270 kg/ha), calcium dihydrogen phosphate (50 kg/ha), and potassium sulfate $(250 \mathrm{~kg} / \mathrm{ha})$ prior to planting. After set emergence, additional fertilizer (ammonium nitrate at $9.5 \mathrm{~kg} / \mathrm{ha}$, calcium dihydrogen phosphate at $6 \mathrm{~kg} / \mathrm{ha}$, and potassium sulfate at $63 \mathrm{~kg} / \mathrm{ha}$ ) was applied to plots of treatments C and D. These treatments were included to compensate for any nutrient addition supplied by the compost applications. Onion sets (cv. Hercules, an early-maturing Sturon type) were planted in April 2004 and emergence was assessed in April and May 2004. Onion sets dipped in Folicur were used in treatments B and D. The number of AWR-affected plants was assessed in June, July, and August 2004. Soil from the various treatment plots was sampled and plated onto PDA containing chlortetracycline at $20 \mathrm{mg} / \mathrm{liter}$ (38) and Triton X-100 at $2 \mathrm{ml} / \mathrm{liter}$ (31) to determine the population of Trichoderma spp. present before and after the application of the $T$. viride S17A inoculum. Bulbs were harvested in September 2004.

The trial was arranged as an extended Trojan square design for five replicates of 12 treatments (Table 2, A to L), in a 5 row-by12-column array of plots. Each row of the design contained a complete replicate of the treatment set, with each set of three adjacent columns (main column) containing each treatment at least once and a different set of three treatments repeated in each main column. This form of design allowed for spatial variation within both rows and main columns, but enabled data to be subjected to analysis of variance.

Some data, including CFU data for Trichoderma spp., were collected only for a subset of the plots; where this subset did not fully correspond to design structures used for the trial, simpler analyses assuming either a completely randomized design or a randomized complete block design were used.

All analyses were performed using GenStat for Windows (Seventh Edition; VSN International Limited, Hemel Hempstead, UK). For variables where transformed values were analyzed, least significant difference values presented in the results relate to transformed values for comparisons between two means.

\section{RESULTS}

Effect of composts and $T$. viride S17A treatments on sclerotia viability, AWR, and plant growth in pot bioassays. In pot bioassay $1 \mathrm{~A}$, the viability of sclerotia was significantly reduced by soil amendment with 42 to $66^{\circ} \mathrm{C}$ OWC $\left(\mathrm{t}_{512}=8.618, P<\right.$ $0.001), 70^{\circ} \mathrm{C} \mathrm{OWC}\left(\mathrm{t}_{512}=4.891, P<0.001\right)$, and irradiated $\mathrm{OWC}$
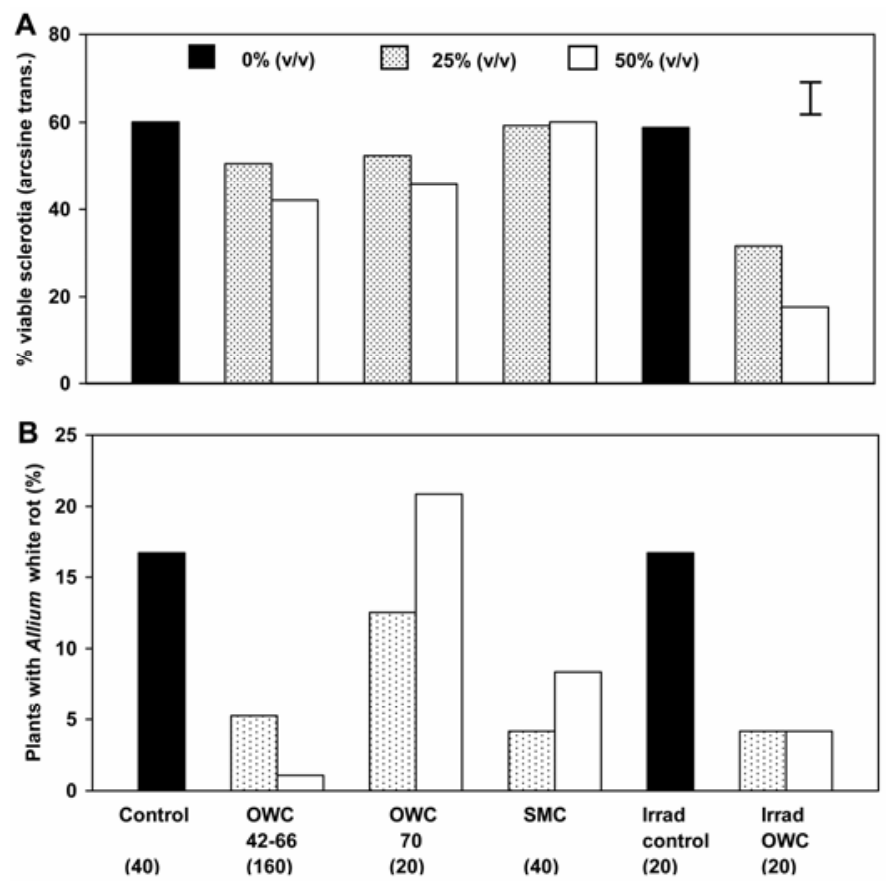

Fig. 1. Effect of compost type and rate in soil, incubation temperature of onion waste compost $(\mathrm{OWC})\left(42\right.$ to $66^{\circ} \mathrm{C}$ and $\left.70^{\circ} \mathrm{C}\right)$, and irradiation (irrad) of soil and soil + OWC in pot bioassay 1. A, Percentage of viable sclerotia retrieved (arcsine transformed) averaged across burial period and replicate; Max least significant difference shown $\left(P=0.05,512 \mathrm{df}, \mathrm{n}_{1}=20 ; \mathrm{n}_{2}=20\right)$. B, Allium white rot (values obtained from predicted mean proportions, averaged across replicate from the generalized linear model analysis). Numbers of replicates $(n)$ for controls and 25 and $50 \%$ vol/vol rates. SMC $=$ spent mushroom compost.

TABLE 2. Treatments and date of application in field trial $2(2002-2004)^{\mathrm{a}}$

\begin{tabular}{|c|c|c|}
\hline Code & Compost application or other treatment $\mathrm{t}^{\mathrm{b}}$ & Date of compost application \\
\hline A & Control (untreated soil or sets) & No compost \\
\hline B & Folicur-dipped sets & No compost \\
\hline $\mathrm{C}$ & Additional fertilizer & No compost \\
\hline $\mathrm{D}$ & Folicur-dipped sets + additional fertilizer & No compost \\
\hline $\mathrm{E}$ & OWC & September 2002 (year 1) \\
\hline $\mathrm{F}$ & OWC & September 2003 (year 2) \\
\hline $\mathrm{G}$ & OWC & September $2002+2003$ (years $1+2)$ \\
\hline $\mathrm{H}$ & $\mathrm{OWC}+$ Trichoderma viride $\mathrm{S} 17 \mathrm{~A}$ & September 2003 (year 2) \\
\hline I & SMC & September 2002 (year 1) \\
\hline $\mathrm{J}$ & SMC & September 2003 (year 2) \\
\hline K & SMC & September $2002+2003($ years $1+2)$ \\
\hline $\mathrm{L}$ & $\mathrm{SMC}+T$. viride $\mathrm{S} 17 \mathrm{~A}$ & September 2003 (year 2) \\
\hline $\mathrm{M}^{\mathrm{c}}$ & Control $+T$. viride $\mathrm{S} 17 \mathrm{~A}$ & No compost \\
\hline
\end{tabular}

a Onion sets (cv. Hercules) were planted April 2004. There were five plots per treatment.

${ }^{\mathrm{b}} \mathrm{OWC}=$ onion waste compost and $\mathrm{SMC}=$ spent mushroom compost.

c In adjacent plots, not part of main design. 
$\left(\mathrm{t}_{512}=11.897, P<0.001\right)$ compared with controls (soil or irradiated soil alone) (Fig. 1A). The $50 \%$ rates of these treatments were significantly more effective in reducing sclerotia viability than the $25 \%$ rates $\left(\mathrm{t}_{512}=8.984, P<0.001 ; \mathrm{t}_{512}=2.074, P=0.039\right.$; and $\mathrm{t}_{512}=5.188, P<0.001$, respectively). There was no difference in effect between the $50^{\circ} \mathrm{C}$ aerated and $50^{\circ} \mathrm{C}$ anaerobic OWC treatments (data not shown). Irradiated OWC was the most effective OWC treatment in reducing sclerotia viability. The reduction in viability increased over time with the 42 to 66 and $70^{\circ} \mathrm{C} \mathrm{OWC}$ treatments (data not shown). The SMC (Fig. 1A) and YTC (data not shown) treatments had no effect on sclerotia viability compared with the control.

In pot bioassay $1 \mathrm{~B}$, soil amendment with 42 to $66^{\circ} \mathrm{C}$ OWC significantly reduced AWR compared with the controls $\left(\mathrm{t}_{98}=\right.$ $3.76, P<0.001$ ), with the $50 \%$ rate being significantly more effective in reducing AWR than the $25 \%$ rate $\left(\mathrm{t}_{98}=2.080, P=\right.$ 0.040) (Fig. 1B). There was no difference in effect between the $50^{\circ} \mathrm{C}$ aerated and $50^{\circ} \mathrm{C}$ anaerobic OWC treatments (data not shown). The $70^{\circ} \mathrm{C}$ OWC had no significant effect on AWR (Fig. $1 \mathrm{~B})$. Due to the low level of AWR in this bioassay, no significant differences were detected between the control and the SMC (Fig. 1B), YTC (data not shown), and irradiated OWC (Fig. 1B) treatments. There was no significant difference between the percentage of non-AWR deaths in the controls (average 13\%) and any of the compost-amended treatments (1 to 17\%) (data not shown).

In pot bioassay $2 \mathrm{~A}$, the viability of sclerotia was significantly reduced by soil amendment with OWC $\left(\mathrm{t}_{217}=9.878, P<0.001\right)$, $\mathrm{OWC}+T$. viride S17A $\left(\mathrm{t}_{217}=9.636, P<0.001\right)$, and irradiated OWC $\left(\mathrm{t}_{217}=11.541, P<0.001\right)$ compared with controls (soil, soil + T. viride S17A, or irradiated soil) (Fig. 2A). The $50 \%$ rate of OWC was significantly more effective in reducing sclerotia viability than the $25 \%$ rate $\left(t_{217}=3.683, P<0.001\right)$. The addition of $T$. viride $\mathrm{S} 17 \mathrm{~A}$ to $\mathrm{OWC}$ did not enhance the effect of the OWC on sclerotia viability. Irradiated OWC was the most effective OWC treatment in reducing sclerotia viability. The reduction in viability with the OWC treatments increased over time (data not shown). The SMC treatments, with or without $T$. viride S17A, had no effect on sclerotia viability compared with controls (Fig. 2A).

In pot bioassay $2 \mathrm{~B}, T$. viride $\mathrm{S} 17 \mathrm{~A}$, both rates of $\mathrm{OWC}$, and the $50 \%$ rate of SMC significantly reduced AWR compared with the control (T. viride S17A t $\mathrm{A}_{48}=1.75, P=0.044 ; 25 \% \mathrm{OWC}_{48}=$ 2.69, $P=0.005 ; 50 \%$ OWC t $_{48}=3.84, P<0.001 ; 50 \% \mathrm{SMC} \mathrm{t}_{48}=$ $2.49, P=0.008)$, with the $50 \%$ rate of OWC being the most effective (Fig. 2B). T. viride S17A had no significant effect on the control of AWR obtained with the composts. Both rates of irradiated OWC and irradiated SMC significantly reduced AWR compared with the irradiated (irrad) control (25\% irrad OWC t $48=1.68, P=$ $0.05 ; 50 \%$ irrad OWC $\mathrm{t}_{48}=3.49, P<0.001 ; 25 \%$ irrad SMC $\mathrm{t}_{48}=$ 2.26, $P=0.015$ ) with the $50 \%$ rate of irradiated SMC being the most effective (no AWR observed) (Fig. 2B). Irradiation had no effect on the control obtained with OWC.

There was no significant difference between the percentage of non-AWR deaths in the controls (0 to $8 \%)$ and any of the compost-amended treatments ( 0 to $16 \%$ ) (data not shown). There was no AWR in any of the plants grown in soil or soil + compost mixtures without sclerotia added.

In pot bioassay $2 \mathrm{~B}$, in the absence of sclerotia, both the OWC and SMC significantly increased plant weight compared with the control $\left(\mathrm{t}_{24}=5.153, P<0.001\right.$ and $\mathrm{t}_{24}=9.018, P<0.001$, respectively); the largest increase was obtained with the $50 \%$ rate of SMC (Fig. 2C). The addition of $T$. viride S17A to soil significantly increased plant weight relative to the soil alone $\left(\mathrm{t}_{24}=\right.$ $2.161, P=0.041)$ but had no effect when added to the composts compared with the composts alone. Irradiation of unamended soil (irradiated control) significantly increased plant weight compared with the nonirradiated control $\left(\mathrm{t}_{24}=3.573, P=0.002\right)$ (Fig. 2C). Irradiation of OWC had no significant effect on plant growth compared with the nonirradiated OWC, whereas irradiation of SMC had inconsistent effects between the two rates.

Analysis of composts. The dry matter content (percent wt/wt) of the OWC, SMC, and YTC were 20 to 24,41 to 52, and 61 to 73 , respectively. The ash content (percent wt/wt of dry matter) of the OWC, SMC, and YTC were 6 to 13,36 to 48 , and 55 to 58 , respectively. The $\mathrm{pH}$ of the OWC, SMC, and YTC were 4.7 to 4.9, 7.0 to 7.2 , and 7.6 to 7.8 , respectively.

A number of volatile sulfur-containing compounds were detected in the OWC (composted at 42 to $70^{\circ} \mathrm{C}$ ) at the following mean ( \pm standard error [SE]) concentrations (per gram of fresh sample): methyl-propyl disulfide $(27.8 \pm 5.96 \mu \mathrm{g} / \mathrm{g})$, isopropyl disulfide $(29.0 \pm 10.54 \mu \mathrm{g} / \mathrm{g})$, dipropyl disulfide $(14.5 \pm 4.73 \mu \mathrm{g} / \mathrm{g})$, n-propyl n-butyl disulfide $(6.1 \pm 0.22 \mu \mathrm{g} / \mathrm{g})$, and dibutyl disulfide $(2.5 \pm 0.10 \mu \mathrm{g} / \mathrm{g})$. A breakdown product of the flavor precursor $\mathrm{S}$ 1-propenyl-L-cysteine sulfoxide, 2-methylpent-2-enal $(6,18)$, was detected in the OWC at $20.9 \pm 4.68 \mu \mathrm{g} / \mathrm{g}$ of fresh sample. There
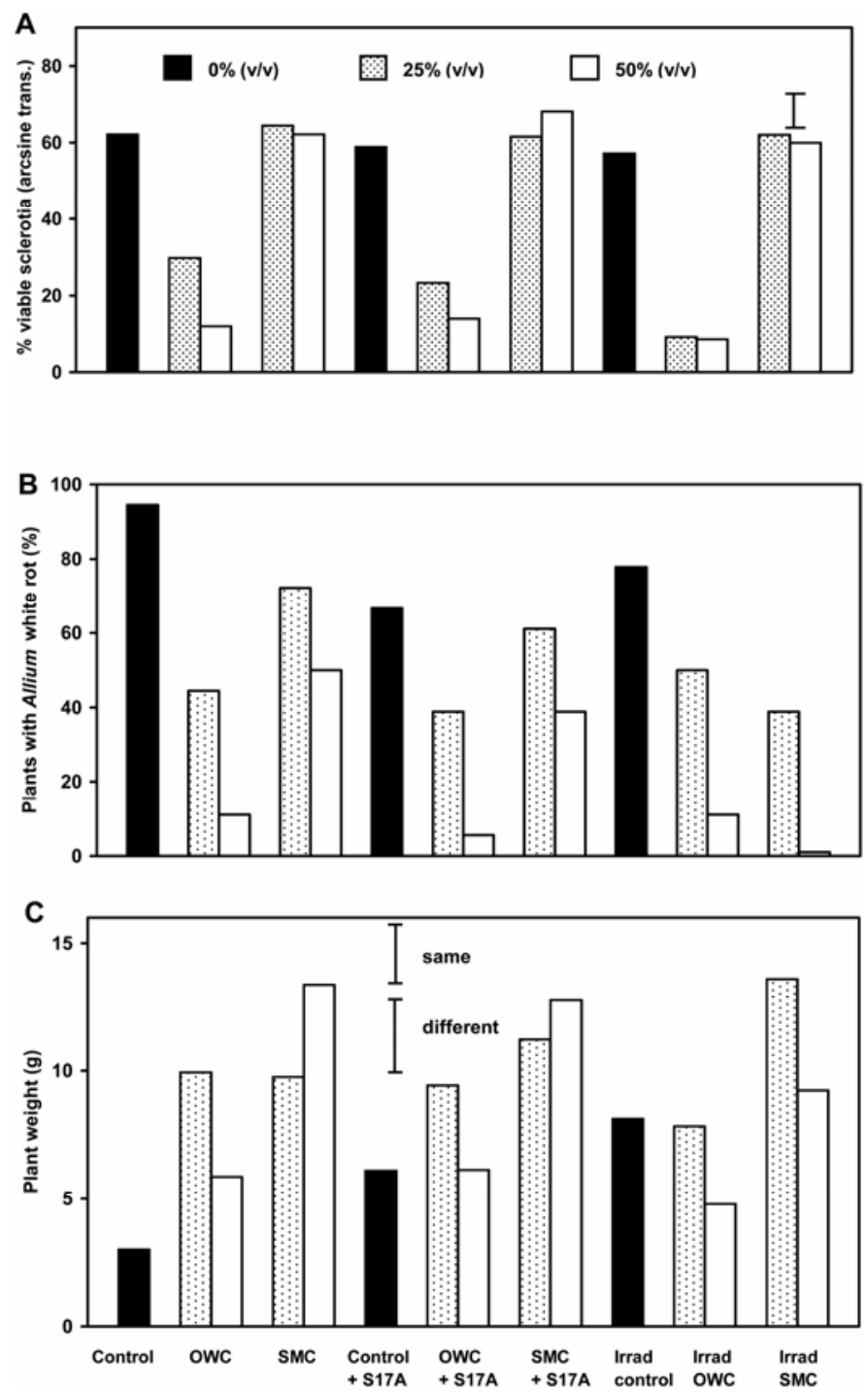

Fig. 2. Effect of compost type and rate in soil, and Trichoderma viride S17A inoculation or irradiation (irrad) of soil and soil + compost in pot bioassay 2 . A, Percentage of viable sclerotia retrieved (arcsine transformed) averaged across burial period and replicate; least significant difference (LSD) shown $(P=0.05,217 \mathrm{df})$. B, Allium white rot (values obtained from predicted mean proportions, averaged across replicate from the generalized linear model analysis). C, Onion plant weight in pots uninoculated with sclerotia. Values are mean weights from three replicates, each consisting of up to six plants; LSD shown $(P=0.05,24 \mathrm{df})$ for comparing means with the same or different additions. $\mathrm{OWC}=$ onion waste compost, $\mathrm{SMC}=$ spent mushroom compost, Irrad $=$ irradiated. 


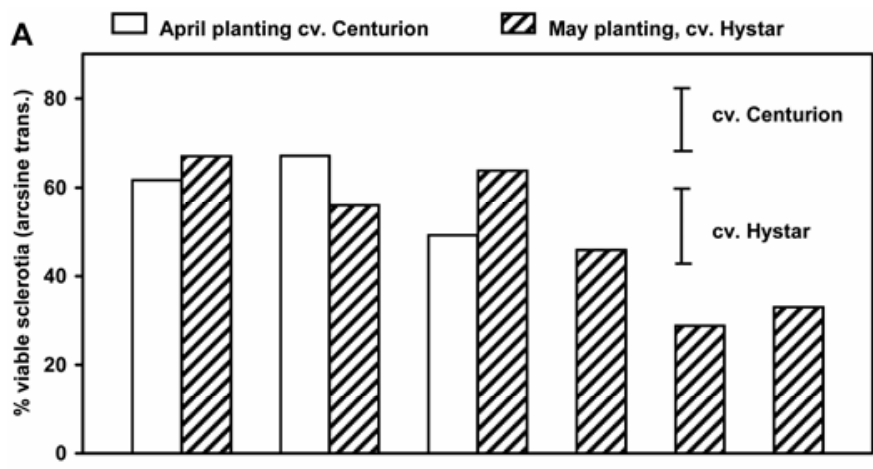

B
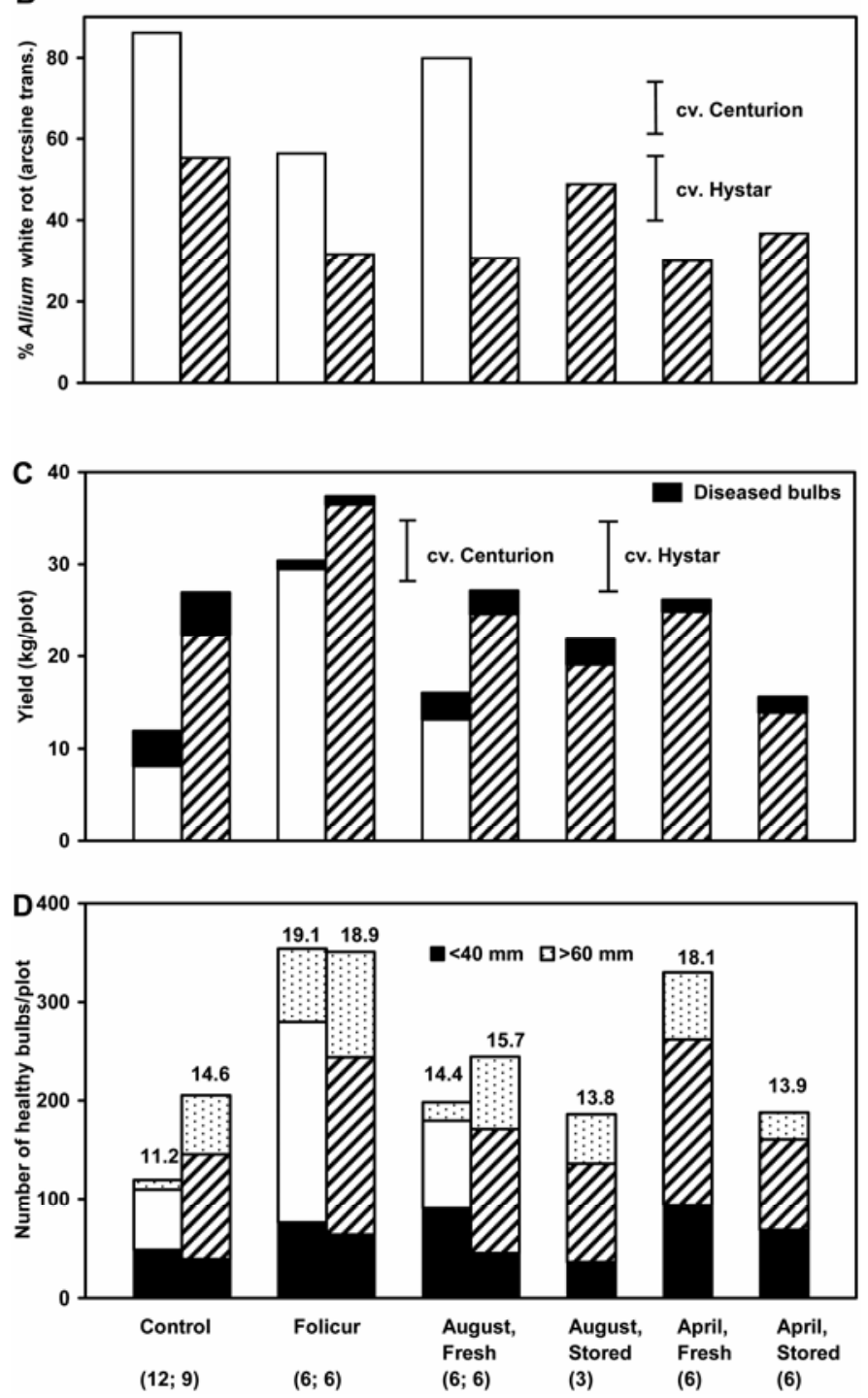

Fig. 3. Effect of onion waste compost (stored or fresh) incorporated in August 2000 or April 2001 and a Folicur dip of sets, in field trial 1. A, Percentage of viable sclerotia retrieved (arcsine transformed) 2 months after set planting in April or May 2001, Max least significant difference (LSD) shown $(P=0.05$, $34 \mathrm{df})$ between treatments cv. Centurion $\left(\mathrm{n}_{1}=6, \mathrm{n}_{2}=6\right)$ and $\mathrm{cv}$. Hystar $\left(\mathrm{n}_{1}=\right.$ $3, \mathrm{n}_{2}=6$ ). B, Cumulative percentage of Allium white rot (AWR) (arcsine transformed), Max LSD shown $(P=0.05,37 \mathrm{df})$ between treatments $\mathrm{cv}$. Centurion $\left(\mathrm{n}_{1}=6, \mathrm{n}_{2}=6\right)$ and cv. Hystar $\left(\mathrm{n}_{1}=3, \mathrm{n}_{2}=6\right)$. C, Total and healthy yields, Max LSD shown $(P=0.05,37 \mathrm{df})$ for total yield between treatments cv. Centurion $\left(\mathrm{n}_{1}=6, \mathrm{n}_{2}=6\right)$ and cv. Hystar $\left(\mathrm{n}_{1}=3, \mathrm{n}_{2}=6\right)$. D, Number of healthy bulbs, subdivided into size grades, Max LSD $(P=0.05,37 \mathrm{df})$ between treatments cv. Centurion $\left(\mathrm{n}_{1}=6, \mathrm{n}_{2}=6\right)=1.7$ and cv. Hystar $\left(\mathrm{n}_{1}=3\right.$, $\mathrm{n}_{2}=6$ ) $=2.1$ (values at the top of bars are square-root-transformed means for the total number of bulbs with AWR). A to $\mathbf{D}$, Values are means across a variable number of replicates as detailed in Table 1 . Numbers of replicates for cv. Centurion and Hystar are shown in parentheses. was no significant effect of composting temperature on the concentrations of sulfur compounds detected in the OWC. No sulfur compounds were detected in the SMC or YTC.

Carboxylic acids were detected in the OWC (composted at 42 to $\left.70^{\circ} \mathrm{C}\right), \mathrm{SMC}$, and YTC at the following mean $( \pm \mathrm{SE})$ concentrations (per gram of fresh sample): acetic acid $(3,787 \pm 446.0 \mu \mathrm{g} / \mathrm{g})$, propionic acid $(264 \pm 50.5 \mu \mathrm{g} / \mathrm{g})$, butyric acid $(5,051 \pm$ $668.9 \mu \mathrm{g} / \mathrm{g})$, valeric acid $(156 \pm 61.5 \mu \mathrm{g} / \mathrm{g})$, iso-butyric acid (94 \pm $36.8 \mu \mathrm{g} / \mathrm{g})$, and iso-valeric acid $(252 \pm 129.3 \mu \mathrm{g} / \mathrm{g})$. There were no significant differences in concentrations of carboxylic acids between compost types due to the variability in concentrations between different batches of the same type.

The following organisms were identified in the OWC produced at $50^{\circ} \mathrm{C}$ : Penicillium sp., Trichoderma sp., Aspergillus sp., Mucor sp., Rhizopus sp., and Doratomyces sp. In contrast, the OWC produced at $70^{\circ} \mathrm{C}$ was colonized predominantly by Penicillium spp.

Field trial 1. Viability of sclerotia buried in plots. Stored OWC applied in August 2000 significantly reduced the percentage of viable sclerotia retrieved 2 months after planting onion sets (cv. Hystar) in May 2001 compared with the untreated control $\left(\mathrm{t}_{34}=\right.$ 2.675, $P=0.011$ ) (Fig. 3A), whereas fresh OWC applied in August 2000 had no significant effect.

The OWC applied in April 2001 significantly reduced the percentage of viable sclerotia retrieved from plots planted in May 2001 compared with the untreated control (stored $\mathrm{t}_{34}=5.304, P<$ 0.001 ; fresh $t_{34}=5.614, P<0.001$ ), although there was no significant difference in effect between stored and fresh OWC (Fig. 3A). Fresh OWC applied in August 2000 significantly reduced the percentage of viable sclerotia retrieved 2 months after planting sets (cv. Centurion) in April 2001 compared with the untreated control $\left(\mathrm{t}_{34}=2.235, P=0.032\right)$; the fungicide treatment had no significant effect.

AWR assessment. AWR infection increased throughout the growing season in each of the treatments. Disease levels were higher on cv. Centurion planted in April than on cv. Hystar planted in May (Fig. 3B). At the time of harvesting, almost all untreated plants of cv. Centurion and more than $60 \%$ of untreated plants of cv. Hystar in the sample lengths were affected by AWR. Control of AWR with the OWC and fungicide treatments, compared with the untreated controls, varied with onion cultivar, the condition of the compost (fresh or stored), and the time of application (Fig. 3B). Fresh OWC applied in August had no significant effect on AWR assessments made during the growing season on cv. Centurion plants, although fungicide treatment of these sets significantly reduced the percentage of plants infected with AWR $\left(\mathrm{t}_{37}=5.360, P<0.001\right)$. The presence of AWR on cv. Hystar plants was significantly reduced by the fungicide treatment $\left(\mathrm{t}_{37}=\right.$ 4.184, $P<0.001$ ) and by all the OWC treatments (August fresh $\mathrm{t}_{37}=3.891, P<0.001 ;$ April fresh $\mathrm{t}_{37}=3.807, P<0.001 ;$ April stored $\mathrm{t}_{37}=2.780, P=0.009$ ), with the exception of stored compost applied in August (Fig. 3B). Control of AWR with the effective compost treatments was comparable with control obtained with the fungicide treatment.

Onion growth and yield. The emergence of sets in untreated control plots differed between cultivars $(66 \%$ for $\mathrm{cv}$. Centurion and $46 \%$ for cv. Hystar). Application of OWC to plots in August 2000 had no significant effect on emergence (63\% for cv. Centurion; $43 \%$ for cv. Hystar). In contrast, emergence from plots treated with OWC in April 2001 (25\%) was significantly lower (stored $\mathrm{t}_{37}=5.269, P<0.001$; fresh $\mathrm{t}_{37}=3.792, P<0.001$ ) than from untreated control plots (46\%). Compared with the above untreated control emergence percentages, the fungicide treatment significantly reduced emergence of cv. Centurion planted in April $(57 \%)\left(\mathrm{t}_{37}=2.113, P=0.042\right)$ but had no effect on cv. Hystar planted in May (46\%). There were phytotoxic symptoms of tip leaf scorch and stunted growth in all the compost treatments.

Fungicide treatment of cv. Centurion sets planted in April significantly increased the healthy gravimetric yield $\left(t_{37}=9.116\right.$, 
$P<0.001)$ and reduced the yield of diseased bulbs $\left(\mathrm{t}_{37}=3.910\right.$, $P<0.001)$ compared with the untreated control, whereas fresh OWC applied in August had no significant effect (Fig. 3C). Fungicide treatment of cv. Hystar sets significantly increased healthy yield $\left(\mathrm{t}_{37}=6.007, P<0.001\right)$ and reduced the yield of diseased bulbs $\left(\mathrm{t}_{37}=4.198, P<0.001\right)$ compared with the untreated control, whereas fresh and stored OWC applied in August and fresh compost applied in April had no effect. However, stored OWC applied in April significantly reduced the total $\left(\mathrm{t}_{37}=4.157, P<\right.$ $0.001)$ and healthy yield $\left(\mathrm{t}_{37}=3.184, P=0.003\right)$ from these sets.

Fresh OWC applied in August significantly increased the total number of healthy cv. Centurion bulbs harvested $\left(\mathrm{t}_{37}=4.375, P<\right.$ $0.001)$ and the number $<40 \mathrm{~mm}\left(\mathrm{t}_{37}=4.129, P<0.001\right)$ and 40 to $60 \mathrm{~mm}$ in diameter $\left(\mathrm{t}_{37}=2.821, P=0.008\right)$ compared with the untreated control, but had no effect on the number and size of the cv. Hystar bulbs (Fig. 3D). Fresh OWC applied in April significantly increased the total number of healthy bulbs harvested $\left(\mathrm{t}_{37}=4.247\right.$, $P<0.001)$ and the number $<40 \mathrm{~mm}\left(\mathrm{t}_{37}=4.882, P<0.001\right)$ and 40 to $60 \mathrm{~mm}$ in diameter $\left(\mathrm{t}_{37}=3.109, P=0.004\right)$ compared with the untreated control. Stored OWC applied in April had no effect on the total number of bulbs harvested but increased the number of bulbs $<40 \mathrm{~mm}$ in diameter compared with the control $\left(\mathrm{t}_{37}=\right.$ $3.109, P=0.004)$. The two August-applied treatments had no effect on the number of healthy cv. Hystar bulbs harvested (Fig. 3D). Fungicide treatment of both Centurion and Hystar sets increased the total number of healthy bulbs harvested (cv. Centurion $\mathrm{t}_{37}=10.608, P<0.001 ; \mathrm{cv}$. Hystar $\left.\mathrm{t}_{37}=5.545, P<0.001\right)$ and the number in each size category compared with the untreated control. There were significant negative correlations between the percentage of AWR-affected plants at the final preharvest assessment and both the number of healthy onions $(r=-0.610 ; n=60)$ and the weight of healthy onions $(r=-0.638 ; n=60)$.

Field trial 2. Viability of sclerotia buried in December 2002. The OWC and SMC applied in year 1 (September 2002) had no effect on the viability of sclerotia retrieved from plots in August 2003 (data not shown). The OWC and SMC applications had a significant effect on the viability of sclerotia retrieved from plots in April 2004 (Fig. 4A). With the exception of OWC applied in year 1, all the OWC treatments significantly reduced overall sclerotia viability compared with the control (year $2 \mathrm{t}_{78}=6.111, P<$ 0.001 ; year $1+2 \mathrm{t}_{78}=5.143, P<0.001 ;+\mathrm{S} 17 \mathrm{~A} \mathrm{t}_{78}=5.401, P<$ $0.001)$. The OWC applied in year 1 reduced the sclerotia recovered and increased the soft sclerotia retrieved compared with the untreated control, whereas the other OWC treatments reduced germination of hard sclerotia (data not shown). The SMC applied in year 2 only significantly reduced sclerotia viability compared with the untreated control $\left(\mathrm{t}_{78}=2.412, P=0.018\right)$ (Fig. 4A), whereas the other SMC treatments, including SMC applied in years 1 and 2, had no effect.

Viability of sclerotia buried in September 2003. The OWC applied in September 2003 significantly reduced the viability of sclerotia retrieved from plots in April 2004 compared with the untreated control $\left(\mathrm{t}_{21}=3.740, P<0.001\right)$ (Fig. 4B), whereas SMC had no effect. Addition of T. viride S17A to OWC or SMC had no

A
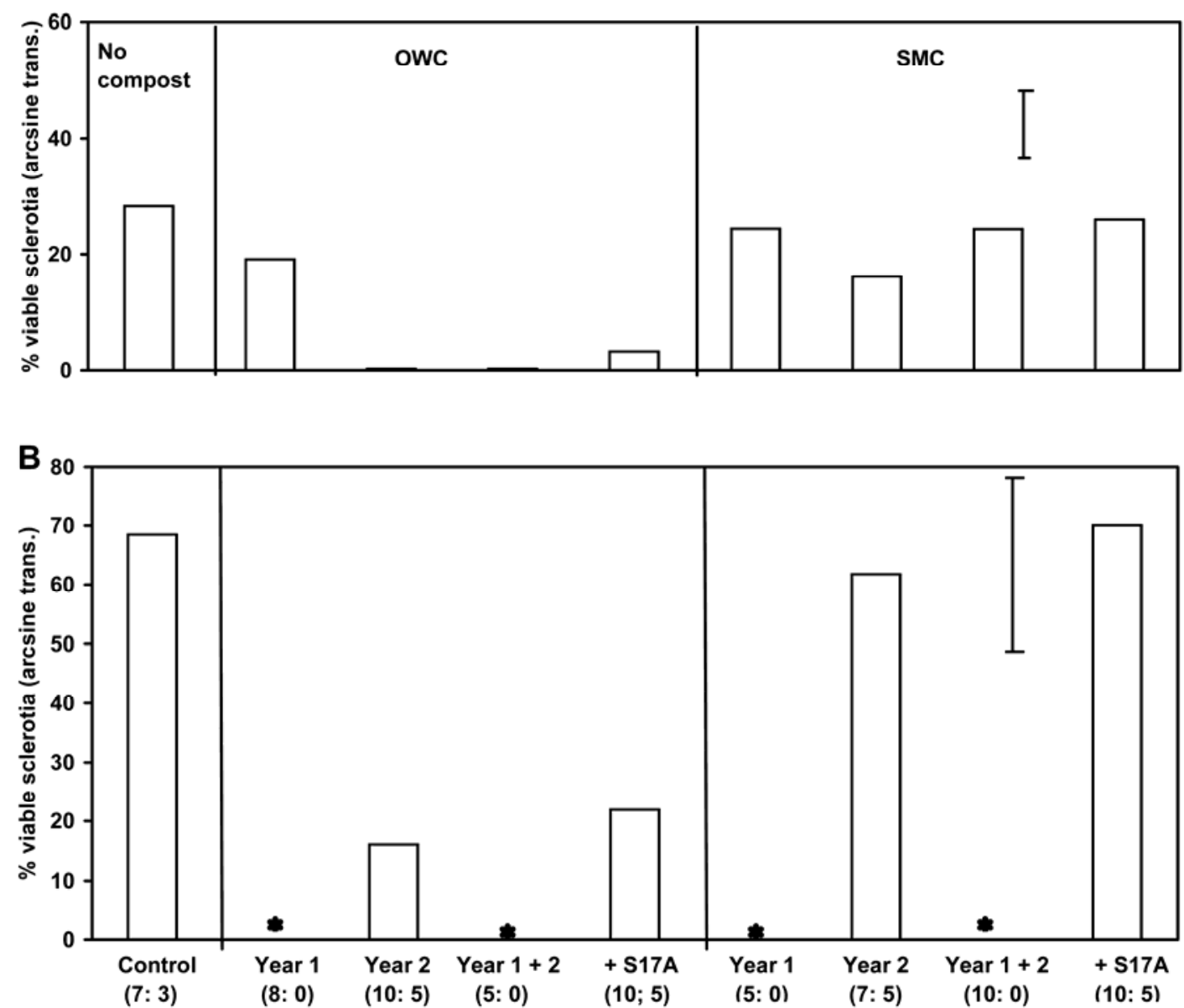

Fig. 4. Effect of incorporation of onion waste compost (OWC) or spent mushroom compost (SMC), with and without Trichoderma viride S17A inoculum, on the percentage of viable sclerotia retrieved (arcsine transformed) in April 2004 in field trial 2. A, Sclerotia buried in December 2002, Max least significant difference (LSD) shown $\left(P=0.05,78 \mathrm{df}, \mathrm{n}_{1}=5 ; \mathrm{n}_{2}=5\right)$. B, Sclerotia buried in September 2003, Max LSD shown $\left(P=0.05,21 \mathrm{df}, \mathrm{n}_{1}=3 ; \mathrm{n}_{2}=5\right) ; *=$ no sclerotia were buried in these treatment plots at this time. Values are means across five replicate plots. Numbers of replicates for $\mathbf{A}$ and $\mathbf{B}$, respectively, are shown in parentheses. Data for Folicur, fertilizer, and Folicur + fertilizer treatments are not shown. 
significant effect on sclerotia viability compared with the year 2 compost treatments alone (Fig. 4A and B).

AWR assessment. AWR infection increased throughout the growing season in each of the treatments. At the time of the final assessment in the field, almost all plants in the sample lengths in the untreated (control), fertilizer-only applied, and all the SMC treatment plots were affected with AWR (Fig. 5A). In contrast, all the OWC treatments (year $1 \mathrm{t}_{41}=7.403, P<0.001$; year $2 \mathrm{t}_{41}=$ $8.193, P<0.001$; year $1+2 \mathrm{t}_{41}=8.720, P<0.001 ;+{\mathrm{S} 17 \mathrm{At}_{41}=}$ 7.767, $P<0.001$ ) and the two fungicide treatments (Folicur $\mathrm{t}_{41}=$ 8.996, $P<0.001$, Folicur + fertilizer $\left.\mathrm{t}_{41}=8.532, P<0.001\right)$ significantly reduced the level of AWR compared with the untreated control. The control achieved with the OWC treatments was comparable with that obtained with the fungicide treatments. Addition of $T$. viride S17A inoculum to soil in adjacent plots along the edges of the main trial did not significantly affect AWR (68\% of plants with AWR compared with $81 \%$ in untreated adjacent plots).

Trichoderma spp. population-September 2003. The SMC application to plots in September 2003 significantly increased the population of Trichoderma spp. compared with unamended soil $\left(\mathrm{t}_{16}=3.022, P=0.008\right)$ (Table 3$)$. However, addition of $T$. viride
S17A inoculum to SMC did not significantly further increase the Trichoderma spp. population. Application of T. viride S17A inoculum and OWC together to plots significantly increased the Trichoderma spp. population $\left(\mathrm{t}_{16}=3.056, P=0.008\right)$ but, applied separately, they had no effect. There was no significant difference between the Trichoderma spp. population in the $\mathrm{OWC}+T$. viride $\mathrm{S} 17 \mathrm{~A}$ and $\mathrm{SMC}+T$. viride $\mathrm{S} 17 \mathrm{~A}$ treatments.

Trichoderma spp. population-July 2004. The population density of Trichoderma spp. was lower in all treatments 10 months after the initial assessment (Table 3). The level of Trichoderma spp. in the soil + SMC treatments was significantly higher compared with soil alone $\left(\mathrm{t}_{15}=2.736, P=0.015\right)$, whereas $T$. viride S17A addition had no significant effect.

Onion growth and yield. No symptoms of phytotoxicity were apparent in the wheat crop that preceded the onion crop on the trial site. In contrast to field trial 1 , none of the treatments affected the emergence of sets or caused phytotoxicity symptoms (data not shown).

Compared with the untreated control, all the fungicide, OWC, and the $\mathrm{SMC}+T$. viride $\mathrm{S} 17 \mathrm{~A}$ treatments significantly increased the yield of healthy onions harvested (Folicur $\mathrm{t}_{41}=8.964, P<$ 0.001; Folicur + fertilizer $\mathrm{t}_{41}=8.657, P<0.001$; OWC year $1 \mathrm{t}_{41}=$
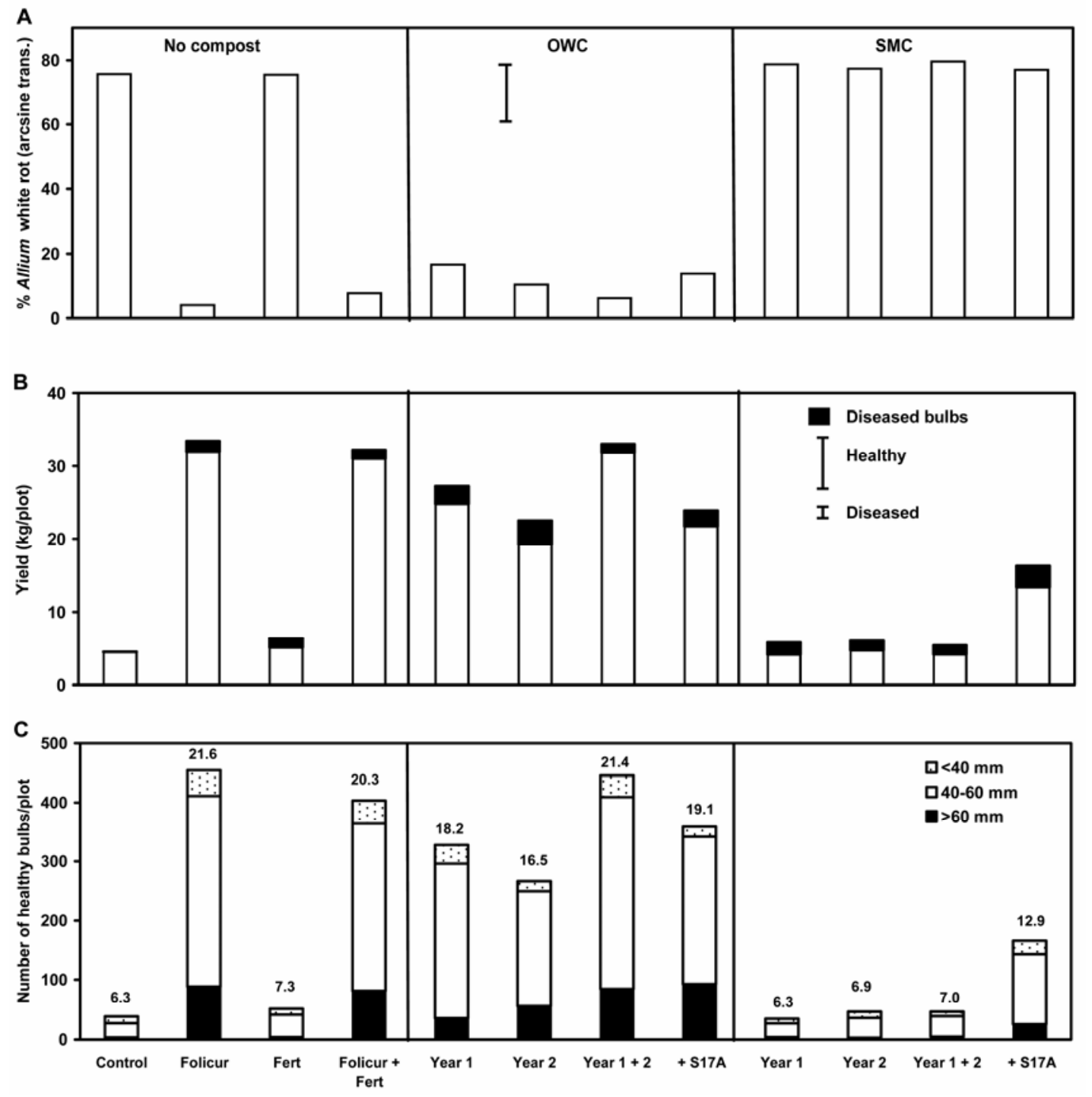

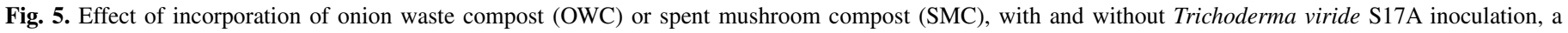

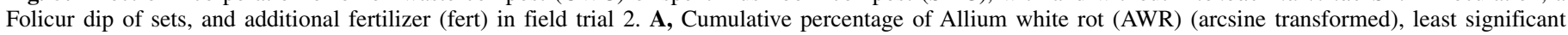

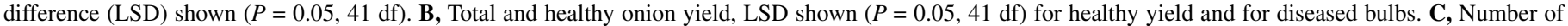

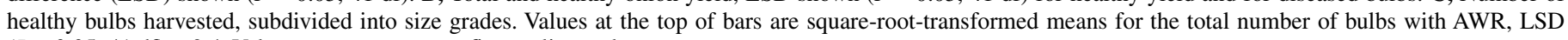
$(P=0.05,41 \mathrm{df})=2.4$. Values are means across five replicate plots. 
6.632, $P<0.001$; year $2 \mathrm{t}_{41}=4.806, P<0.001$; year $1+2 \mathrm{t}_{41}=$ 8.932, $P<0.001 ; \mathrm{OWC}+\mathrm{S}_{17 \mathrm{~A} \mathrm{t}} \mathrm{H}_{41}=5.622, P<0.001 ; \mathrm{SMC}+$ S17A t $\mathrm{t}_{41}=2.888, P=0.006$ ) (Fig. 5B) and the total number of healthy bulbs harvested (Folicur $\mathrm{t}_{41}=12.884, P<0.001$; Folicur + fertilizer $\mathrm{t}_{41}=11.762, P<0.001$; OWC year $1 \mathrm{t}_{41}=10.008, P<$ 0.001 ; year $2 \mathrm{t}_{41}=8.592, P<0.001$; year $1+2 \mathrm{t}_{41}=12.732, P<$

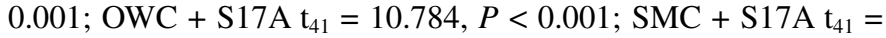
5.582, $P<0.001$ ) (Fig. 5C). However, the OWC (year $1 \mathrm{t}_{41}=$ $2.190, P=0.034$ ), OWC (year $2 \mathrm{t}_{41}=3.565, P=0.001$ ), and $\mathrm{SMC}+T$. viride $\mathrm{S} 17 \mathrm{~A}\left(\mathrm{t}_{41}=2.991, P=0.005\right)$ treatments significantly increased the diseased yield compared with the untreated control (Fig. 5B), a result of most of the plants in the untreated plots being lost to AWR throughout the growing season and, hence, fewer bulbs being present for assessment at harvest. The addition of the $T$. viride S17A inoculum to soil in adjacent plots along the edges of the main trial did not significantly affect the yield of healthy onion bulbs harvested $(13.7 \mathrm{~kg} / \mathrm{plot}$ compared with $9.5 \mathrm{~kg} /$ plot in untreated adjacent plots).

Both fungicide treatments, OWC (year 1), and OWC (year $1+$ 2) treatments increased the number of healthy bulbs in all three size categories compared with the untreated control (Fig. 5C). In addition, the OWC (year 2), OWC $+T$. viride $\mathrm{S} 17 \mathrm{~A}$, and $\mathrm{SMC}+$ T. viride S17A treatments increased the number of healthy bulbs in the $<40-\mathrm{mm}$ - and 40-to-60-mm-diameter size categories. There were strong negative correlations between the percentage of AWR-affected plants at the final preharvest assessment and both the number of healthy onion bulbs $(r=-0.934 ; n=60)$ and the weight of healthy onion bulbs $(r=-0.875 ; n=60)$.
Environmental conditions in glasshouse and field. In the glasshouse, the average air temperature during the course of the sclerotia viability pot bioassays (bioassays $1 \mathrm{~A}$ and $2 \mathrm{~A}$ ) was $17^{\circ} \mathrm{C}$, with average temperatures of 16 and $14^{\circ} \mathrm{C}$ in the AWR pot bioassays $1 \mathrm{~B}$ and $2 \mathrm{~B}$, respectively (Fig. 6).

In field trial 1 , the average soil temperature at a depth of $100 \mathrm{~mm}$ during the period from the first compost application to set planting (August 2000 to May 2001) was $8^{\circ} \mathrm{C}$ (Fig. 6). The average soil temperature from set planting to harvest was $14^{\circ} \mathrm{C}$ for $\mathrm{cv}$. Centurion and $16^{\circ} \mathrm{C}$ for $\mathrm{cv}$. Hystar.

In field trial 2, the average soil temperature during the burial period for the sclerotia buried in December 2002 and retrieved prior to set planting (December 2002 to April 2004) was $9^{\circ} \mathrm{C}$ (Fig. 6 ). The average soil temperature during the burial period for the sclerotia buried in September 2003 (September 2003 to April 2004) was $7^{\circ} \mathrm{C}$. The average soil temperature from set planting to harvest was $15^{\circ} \mathrm{C}$.

\section{DISCUSSION}

Organic amendments made to soil generally have been more effective in suppressing soilborne diseases in glasshouse pot bioassays than in field experiments (28). This can be attributed to the warmer conditions in the glasshouse, which encourage antagonism of pathogens by soil microbiota and release of toxic volatiles (34) and the better incorporation of compost with soil in small-scale tests (28). However, in agreement with previous work $(14,15)$, OWC amendment of soil reduced the viability of $S$. cepi-

TABLE 3. Trichoderma spp. (CFU/g of soil) recovered from treatment plots in September 2003 (2 weeks after application) and July 2004 (10 months after application $)^{\mathrm{a}}$

\begin{tabular}{llll}
\hline Code & \multicolumn{1}{c}{ Treatment $\left(\mathrm{n}_{1} ; \mathrm{n}_{2}\right)^{\mathrm{b}}$} & September 2003 & July 2004 \\
\hline A & Control: untreated soil $(3 ; 4)$ & $3.8 \times 10^{4}(4.58)$ & $3.8 \times 10^{1}(1.58)$ \\
F & Soil + OWC (3; 4) & $2.8 \times 10^{4}(4.45)$ & $3.8 \times 10^{1}(1.58)$ \\
J & Soil + SMC (3; 3) & $2.3 \times 10^{6}(6.36)$ & $2.9 \times 10^{3}(3.47)$ \\
H & Soil + OWC + Trichoderma viride S17A inoculum $(3 ; 5)$ & $2.4 \times 10^{6}(6.38)$ & $1.6 \times 10^{2}(2.22)$ \\
L & Soil + SMC + T. viride S17A inoculum (3; 4) & $1.4 \times 10^{6}(6.14)$ & $5.5 \times 10^{2}(2.74)$ \\
M & Soil + T. viride S17A inoculum (3; 0) & $6.7 \times 10^{4}(4.83)$ & nd \\
LSD $(P=0.05)$ & $\ldots$ & $1.25^{\mathrm{c}}$ & $1.47^{\mathrm{d}}$ \\
\hline
\end{tabular}

${ }^{a}$ Back-transformed mean counts from replicate plots in each treatment with $\log _{10}$-transformed means shown in parentheses. Least significant difference (LSD) values are for $\log _{10}$-transformed data and relate to comparison between two means; nd = not determined.

${ }^{\mathrm{b}}$ Replications for September $2003\left(\mathrm{n}_{1}\right)$ and July $2004\left(\mathrm{n}_{2}\right)$; OWC = onion waste compost and SMC = spent mushroom compost.

${ }^{c}$ LSD on $16 \mathrm{df}$.

${ }^{\mathrm{d}} \mathrm{LSD}$ on $15 \mathrm{df}$ for means with three and four replicates, respectively.

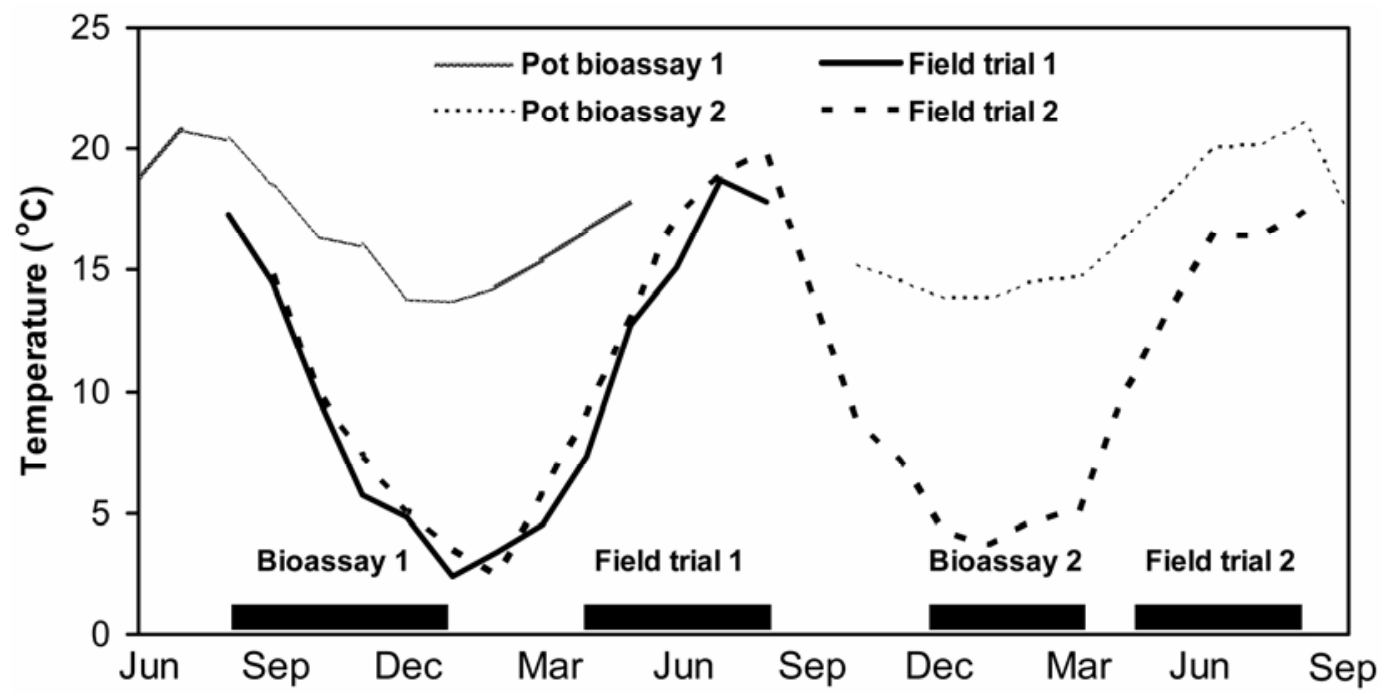

Fig. 6. Mean monthly soil temperatures, at a depth of $100 \mathrm{~mm}$, for field trials 1 (August 2000 to August 2001) and 2 (September 2002 to August 2004 ) and air temperatures for glasshouse pot bioassays 1 (June 2002 to May 2003) and 2 (October 2003 to September 2004). Horizontal bars indicate the growing period for the onions in the bioassays and field trials. 
vorum sclerotia under glasshouse and field conditions, and suppressed AWR in glasshouse bioassays. Amendment of soil with OWC also suppressed AWR in the field, despite the much-lower sclerotia population needed to cause disease than in pot bioassays. This difference between plants in individual pots and in field plots also was observed by Rahe (32), who attributed it to plant-toplant infection by $S$. cepivorum in the field.

In contrast with the results of the sclerotia pot bioassays, loss of sclerotia viability in the field did not increase with contact time between the OWC and sclerotia. In field trial 1, the OWC applied to the field plots in April generally was more effective in reducing sclerotia viability than OWC applied in the previous August. In addition, in field trial 2, a greater reduction in sclerotia viability was observed in sclerotia retrieved from plots with the shortest contact time with the waste, although all the OWC treatments reduced viability compared with the control. Because $S$. cepivorum is most active at a temperature of approximately $15^{\circ} \mathrm{C}(17)$, the low fall and winter temperatures following compost application in August and September may have reduced the activity of $S$. cepivorum and of potential antagonists, or the release of volatile sulfur compounds. Therefore, the time of year when compost is applied to land is likely to have an important effect on viability of sclerotia and AWR control.

Levels of AWR and its control with the OWC treatments in field trial 1 differed between the early- and late-planted cultivars. The high disease levels in cv. Centurion, planted 1 month before cv. Hystar, may have masked disease control by the compost treatments. Sclerotia are stimulated to germinate in the presence of Allium spp. under favorable conditions for the pathogen and sclerotial germination varies with onion cultivar, the size of the root system, and seasonal conditions (17). The early-planted cultivar may have developed a root system when temperatures were favorable for the pathogen, whereas the root system of the later cultivar would have developed when temperatures were higher and less favorable for $S$. cepivorum.

In field trial 1, control of AWR with the effective OWC treatments was comparable with the control obtained with the fungicide (tebuconazole) treatment at high disease pressures $(65 \%$ of untreated cv. Hystar plants with AWR). At very high disease pressures ( $100 \%$ of untreated cv. Centurion plants with AWR), control with the fungicide treatment was significantly better than with OWC treatments. In field trial 2, using cv. Hercules, a Sturon-type bulb similar to cv. Centurion (94\% of untreated plants with AWR), disease control comparable with the fungicide treatment was achieved with all the OWC treatments. The viability of sclerotia recovered from the plots prior to set planting was higher in field trial 1 compared with field trial 2, although the same inoculum of $S$. cepivorum sclerotia was added to the soil at the start of both trials. The field trials were conducted in different years and, therefore, the sclerotia in the trials were exposed to different environmental conditions. The surviving sclerotia in field trial 2 also were exposed to an additional conditioning period (7) of 1 year before planting onion sets, which may have enhanced their virulence.

Suppression of AWR in soil in pot bioassays with mycelial inoculum of $T$. viride S17A confirms previous suppressive effects using a wheat bran culture $(8,9)$. Plant-to-plant infection, as described earlier, may explain why the $\mathrm{SMC}+T$. viride S17A treatment of soil increased healthy bulb yield over the entire plot, but did not affect AWR assessments made in the center of plots where AWR infection was highest. Therefore, the addition of the T. viride S17A inoculum to the SMC may have had an AWR control effect in areas with lower disease pressure, and this was reflected in an increased healthy yield. This suppression of AWR with $T$. viride S17A in the presence of the SMC occurred without a reduction in viable sclerotia. Clarkson et al. (9) found that T. viride S17A could degrade sclerotia and suppress AWR. However, a third of the biocontrol agents they tested, including other
Trichoderma spp., were able to control AWR on onion seedlings but caused little or no degradation of sclerotia. Metcalf and Wilson (27) showed that $T$. koningii colonized $S$. cepivorum-infected onion roots and antagonized $S$. cepivorum by the production of chitin-degrading enzymes. Therefore, antagonism of $S$. cepivorum by Trichoderma spp. may occur by lysis of hyphae, as well as by parasitism of sclerotia (1).

The results here have shown that the initial proliferation of T. viride $\mathrm{S} 17 \mathrm{~A}$ in field soil and subsequent control of AWR is facilitated by application with SMC as a carrier. Further work is needed to optimize the growth of $T$. viride on compost. The use of composts as a carrier for disease suppressive agents such as Trichoderma spp. is established for container potting media (28). Metcalf et al. (26) have developed this approach for field-scale control of AWR using YTC inoculated with T. koningii.

The efficacy of OWC and T. viride S17A + compost in controlling AWR or increasing bulb survival in the field was predicted from the pot bioassay results with the same treatments. However, unlike the pot bioassay results, SMC was ineffective in controlling AWR or increasing bulb survival in the field. Therefore, suppression of AWR with SMC may be more sensitive to environmental conditions than suppression with OWC or $T$. viride S17A + compost.

In field trial 1, where OWC was applied 1 to 8 months before planting of sets, phytotoxicity in terms of reduced emergence or tip leaf scorch symptoms was observed. None of the OWC treatments improved healthy yield compared with the untreated control despite their AWR-suppressive effects. This was due to a reduction in bulb size and is a further indication of the phytotoxicity of the OWC, possibly due to the carboxylic acid content (22). Phytotoxic compounds have been shown to increase in soil following compost incorporation, but then decline over time (13). This may explain why no phytotoxic symptoms were observed on the onion plants in field trial 2, where compost was applied 7 to 19 months before planting. The negative correlations between the healthy harvest data and the percentage of AWR-affected plants preharvest were stronger for field trial 2 than for field trial 1 . This almost certainly is due to the avoidance of phytotoxicity resulting from OWC application in field trial 2, although application of OWC 7 months preplanting still reduced bulb size. No phytotoxic effects of composts were observed in the pot bioassays; this may be due to the volatilization or degradation of phytotoxic compounds in the warmer glasshouse conditions before planting.

Comparison of effective compost treatments with ineffective compost and fertilizer amendments and unamended soil indicate that changes in soil moisture, $\mathrm{pH}$, electrical conductivity, and the contents of plant nutrients, organic matter (data not shown), and carboxylic acids recorded in this study were not primarily responsible for AWR suppression. The results indicate that, depending on the specific compost or T. viride S17A amendment of soil, AWR is suppressed by (i) a reduction in the viable sclerotia population to below a threshold level needed to cause disease and (ii) prevention of infection of onion plants by sclerotia. Sclerotia degradation (i) was confined almost entirely to OWC. This feature may be due to sulfur compounds in OWC which were not detected in SMC or YTC. However, it is not yet clear whether it is the breakdown products of the sulfoxides that trigger the sclerotia to germinate $(12,14)$ or toxic sulfur compounds $(34)$ which are responsible. Linderman and Gilbert (23) showed that sclerotia of $S$. rolfsii were stimulated to germinate by low doses of volatiles from alfalfa hay, such as acetaldehyde, with high doses being inhibitory or lethal.

Suppression of AWR without loss in sclerotia viability (ii) was observed following soil amendment with SMC in pot bioassays, whereas application of SMC in the field was ineffective in suppressing AWR. This difference in suppression of AWR between glasshouse and field may relate to differences in temperature. In the pot bioassays, the SMC may have encouraged a soil microbi- 
ota to develop which suppressed sclerotia germination or antagonized $S$. cepivorum mycelium after germination (28). After application in the field, the temperatures may have been too low for this to occur. There was also a longer time between application of SMC and onion planting (at least 7 months in the field instead of 2 months in pots), possibly resulting in loss of microbial antagonists. For example, the Trichoderma spp. count from the soil 10 months after SMC application was much lower than after 2 weeks. There was a growth-promoting effect of SMC on onion plants in pots but not in the field, which may have led to greater plant vigor and disease resistance (28).

Sclerotia viability loss (i), was not the only process involved in AWR suppression by OWC. This is demonstrated by onion waste composted at $70^{\circ} \mathrm{C}$ being as effective as onion waste composted at 42 to $66^{\circ} \mathrm{C}$ in degrading sclerotia, but ineffective in suppressing AWR. The diverse microbiota in waste composted at 42 to $66^{\circ} \mathrm{C}$ may have been more antagonistic to $S$. cepivorum than the predominant Penicillium spp. that colonized OWC produced at $70^{\circ} \mathrm{C}$. A greater diversity of species may have survived the lower composting temperature. However, sterilization of compost often results in a loss of disease suppressiveness due to a loss in biological activity $(20,28)$. However, in this study, the suppressiveness of irradiated OWC and SMC indicates that the soil microbiota that subsequently colonized the compost may have been at least as suppressive as the microbial population in the nonirradiated compost. The loss in microbial diversity in OWC produced at $70^{\circ} \mathrm{C}$ also may be due to a loss in available nutrients (e.g., sugars through caramelization) (19).

This work has shown OWC treatments to be effective for controlling AWR using an artificially produced $S$. cepivorum inoculum. Application of OWC to land naturally infested with $S$. cepivorum sclerotia also has been shown to give effective AWR control in commercial onion crops (R. Oldershaw, Goldwood of Moulton Ltd., Lincolnshire, UK, personal communication). In this study, AWR control was not only the result of loss in sclerotia viability; therefore, assessing sclerotia viability did not enable the level of disease to be predicted in all cases. This is supported by Rahe (32), who showed that the level of AWR did not necessarily correspond to the population of $S$. cepivorum sclerotia in soil. A problem previously encountered with the use of composts for suppressing soilborne pathogens is the inconsistency in the level of disease control achieved, caused by the variability of composts, particularly in their microbiota (28). Results obtained in this study showed a consistently high level of AWR control with OWC amendment of soil. This may be due to the sulfur compounds implicated in stimulating sclerotial germination being detected in all the OWC samples used. Storage of OWC resulted in a diminution in disease suppressiveness, but not in efficacy in reducing sclerotia viability. A sufficient delay (more than 7 months) between amendment of soil with OWC and onion planting is needed to avoid phytotoxicity in the crop. This was achieved by sowing an intervening OWC-tolerant crop (wheat) and this did not significantly affect the efficacy of the OWC in controlling AWR. The 75 to $79 \mathrm{t}$ of dry matter/ha $(\approx 1.5 \mathrm{t}$ of $\mathrm{N} / \mathrm{ha})$ would exceed the limit set for the application of nitrogen to land in the European Union Nitrates Directive (170 kg N/ha) (4). Using this rate, it would be possible to treat only areas of fields previously known to be infested with $S$. cepivorum, because AWR is known to be patchy in occurrence (17). However, further work is needed to determine whether lower compost rates than those used here would be effective in controlling AWR at lower and commercially realistic disease pressures of $\approx 15 \%$ of plants infected with AWR (9).

\section{ACKNOWLEDGMENTS}

This research was funded by the Department for Environment, Food and Rural Affairs, the Horticultural Development Council, the other consortium members of Horticulture LINK Project CSA 4802, and the Euro- pean Union (Project QLRT-01458 "RECOVEG"). The T. viride S17A solid substrate inoculum was produced by S. Brueckner, Prophyta GmbH, Malchow/Poel, Germany. We thank H. Banham and G. Clark, Warwick HRI, Kirton, Boston, Lincolnshire for technical assistance.

\section{LITERATURE CITED}

1. Abd-El-Moity, T. H., and Shatla, M. N. 1981. Biological control of the white rot disease of onions (Sclerotium cepivorum) by Trichoderma harzianum. Phytopathol. Z. 100:29-35.

2. Adams, P. B. 1990. The potential of mycoparasites for biological control of plant diseases. Annu. Rev. Phytopathol. 28:59-72.

3. Anonymous. 1986. The analysis of agricultural materials. Pages 219-221 in: Ministry of Agriculture, Fisheries and Food/Agricultural Development and Advisory Service Reference Book 427. HMSO, London.

4. Anonymous 1991. Council Directive of 12 December 1991 concerning the protection of water against pollution caused by nitrates from agricultural sources. Off. J. Eur. Commission, Legislation 34 (L371):1-8.

5. Artacho Martin-Lagos, R., Olea Serrano, M. D., and Ruiz-López, M. D. 1992. Comparative study by gas chromatography-mass spectrometry of methods for the extraction of sulphur compounds in Allium cepa L. Food Chem. 44:305-308.

6. Boelens, M., de Valois, P. J., Wobben, H. J., and van der Gen, A. 1971. Volatile flavor compounds from onion. J. Agric. Food Chem. 19:984-991.

7. Brix, H. D., and Zinkernagel, V. 1992. Effects of cultivation, conditioning and isolate on sclerotium germination of Sclerotium cepivorum. Plant Pathol. 41:13-19.

8. Clarkson, J. P., Mead, A., Payne, T., and Whipps, J. M. 2004. Effect of environmental factors and Sclerotium cepivorum isolate on sclerotial degradation and biological control of white rot by Trichoderma. Plant Pathol. 53:353-362.

9. Clarkson, J. P., Payne, T., Mead, A., and Whipps, J. M. 2002. Selection of fungal biological control agents of Sclerotium cepivorum for control of white rot by sclerotial degradation in a UK soil. Plant Pathol. 51:735-745.

10. Coley-Smith, J. R. 1990. White rot disease of Allium: Problems of soilborne diseases in microcosm. Plant Pathol. 39:214-222.

11. Coley-Smith, J. R., Mitchell, C. M., and Sansford, C. E. 1990. Long-term survival of sclerotia of Sclerotium cepivorum and Stromatinia gladioli. Plant Pathol. 39:58-69.

12. Coley-Smith, J. R., and Parfitt, D. 1986. Some effects of diallyl disulphide on sclerotia of Sclerotium cepivorum: Possible novel control method for white rot disease of onions. Pestic. Sci. 37:587-594.

13. Conklin, A. E., Erich, M. S., Liebman, M., Lambert, D., Gallandt, E. R., and Halteman, W. A. 2002. Effects of red clover (Trifolium pratense) green manure and compost soil amendments on wild mustard (Brassica kaber) growth and incidence of disease. Plant Soil 238:245-256.

14. Coventry, E., Noble, R., Mead, A., and Whipps, J. M. 2002. Control of Allium white rot (Sclerotium cepivorum) with composted onion waste. Soil Biol. Biochem. 34:1037-1045.

15. Coventry, E., Noble, R., Mead, A., and Whipps, J. M. 2005. Suppression of Allium white rot (Sclerotium cepivorum) in different soils using vegetable wastes. Eur. J. Plant Pathol. 111:101-112.

16. Elwell, D. L., Keener, H. M., Wiles, M. C., Borger, D. C., and Willett, L. B. 2001. Odorous emissions and odor control in composting swine manure/sawdust mixes using continuous and intermittent aeration. Trans. ASAE 44:1307-1316.

17. Entwistle, A. R. 1990. Allium white rot and its control. Soil Use Manage. 6:201-209.

18. Freeman, G. G., and Whenham, R. J. 1975. A survey of volatile components of some Allium species in terms of S-alk(en)yl-L-cysteine sulphoxides present as flavour precursors. J. Sci. Food Agric. 26:18691886.

19. Gerrits, J. P. G. 1988. Nutrition and compost. Pages 29-72 in: The Cultivation of Mushrooms. L. J. L. D. van Griensven, ed. Darlington Mushroom Laboratories, Sussex, UK.

20. Gorodecki, B., and Hadar, Y. 1990. Suppression of Rhizoctonia solani and Sclerotium rolfsii in container media containing composted separated cattle manure and composted grape marc. Crop Prot. 9:271-274.

21. Grogan, H. M., Scruby, A., and Harvey, L. 2000. Moulds in spawn-run compost and their effect on mushroom production. Pages 609-615 in: Science and Cultivation of Edible Fungi. Vol. 2. L. J. L. D. van Griensven, ed. A. A. Balkema, Rotterdam, The Netherlands.

22. Keeling, A. A., Paton, I. K., and Mullet, J. A. 1994. Germination and growth of plants in media containing unstable refuse-derived compost. Soil Biol. Biochem. 26:767-772.

23. Linderman, R. G., and Gilbert, R. G. 1975. Influence of volatiles of plant origin on soil-borne plant pathogens. Pages 90-99 in: Biology and Control of Soil-borne Plant Pathogens. G. W. Bruehl, ed. The American Phytopathological Society, St. Paul, MN. 
24. Lumsden, R. D., Lewis, J. A., and Milner, P. D. 1983. Effect of composted sewage sludge on several soilborne pathogens and diseases. Phytopathology 73:1543-1548.

25. Melero-Vara, J. M., Prados-Ligero, A. M., and Basallote-Ureba, M. J. 2000. Comparison of physical, chemical and biological methods of controlling garlic white rot. Eur. J. Plant Pathol. 106:581-588.

26. Metcalf, D., Groom, T., and Van Essen, A. 2003. Tasmanian group establishes new method for control of onion white rot. Onions Aust. 20:26-27.

27. Metcalf, D. A., and Wilson, C. R. 2001. The process of antagonism of Sclerotium cepivorum in white rot affected onion roots by Trichoderma koningii. Plant Pathol. 50:249-257.

28. Noble, R., and Coventry, E. 2005. Suppression of soil-borne plant diseases with composts: A review. Biocontrol Sci. Technol. 15:3-20.

29. Noble, R., Whipps, J. M., and Coventry, E. 2000. An alternative to landfill: Composting onion and other vegetable wastes to control pests and diseases and avoid pollution. Pages 355-360 in: Waste 2000 Conf. Proc. The Waste Conference Limited, The Barclay Centre, University of Warwick Science Park, Coventry, UK.

30. Papavizas, G. C. 1985. Trichoderma and Gliocladium-biology, ecology, and potential for biocontrol. Annu. Rev. Phytopathol. 23:23-54.

31. Postma, J., Geraats, B. P. J., Pastoor, R., and van Elsas, D. J. 2005. Characterization of the microbial community involved in the suppression of Pythium aphanidermatum in cucumber grown on rockwool. Phytopathology 95:808-818.

32. Rahe, J. E. 1979. Lack of correlation between field and laboratory tests for resistance with special reference to white rot of onions. Pages 193-200 in: Plant Disease Control. Resistance and Susceptibility. R. C. Staples and G. H. Toenniessen, eds. John Wiley \& Sons, Inc., New York.

33. Seaby, D. A. 1996. Investigation of the epidemiology of green mould of mushroom (Agaricus bisporus) compost caused by Trichoderma harzianum. Plant Pathol. 45:913-923.

34. Smolinska, U. 2000. Survival of Sclerotium cepivorum sclerotia and Fusarium oxysporum chlamydospores in soil amended with cruciferous residues. J. Phytopathol. 148:343-349.

35. Thompson, R., and Welham, S. J. 2000. REML analysis of mixed models. Pages 413-503 in: The Guide to GenStat-Part 2: Statistics. R. W. Payne, ed. VSN International, Oxford, UK.

36. United States EPA, Office of Pesticide Programs. 2005. Pesticide Product Information System at Oregon State University. Online publication.

37. Walker, A., Brown, P. A., and Entwistle, A. R. 1986. Enhanced degradation of iprodione and vinclozolin in soil. Pestic. Sci. 17:183-193.

38. Williams, R. H., Whipps, J. M., and Cooke, R. C. 1998. Role of soil mesofauna in dispersal of Coniothyrium minitans: Mechanisms of transmission. Soil Biol. Biochem. 30:1937-1945. 